\title{
Second Times Gram per Milliliter
}

National Cancer Institute

\section{Source}

National Cancer Institute. Second Times Gram per Milliliter. NCI Thesaurus. Code C85803.

Seconds times grams per milliliter. 